\title{
Evidence That Protein Disulfide Isomerase in Yeast Saccharomyces cerevisiae Is Transported from the ER to the Golgi Apparatus
}

\author{
Tadashi Miura1 $^{1}$ Yukari Oda² ${ }^{2}$ Yasuhiko Shizawa ${ }^{3}$ \\ ${ }^{1}$ Oral Health Science Center, Tokyo Dental College, Tokyo, Japan; ${ }^{2}$ Department of Oral and Maxillofacial \\ Implantology, Tokyo Dental College, Tokyo, Japan; ${ }^{3}$ Department of Liberal Arts, College of Bioresource Sciences, \\ Nihon University, Kanagawa, Japan
}

Correspondence to: Tadashi Miura, tamiura@tdc.ac.jp

Keywords: Protein Disulfide Isomerase, Endoplasmic Reticulum, Golgi Apparatus, Oligosaccharide Modification, Protein Localization

Received: January 2, $2022 \quad$ Accepted: February 11, $2022 \quad$ Published: February 14, 2022

Copyright $\odot 2022$ by author(s) and Scientific Research Publishing Inc.

This work is licensed under the Creative Commons Attribution International License (CC BY 4.0).

http://creativecommons.org/licenses/by/4.0/

\section{(c) (1) Open Access}

\section{ABSTRACT}

Newly synthesized membrane and secretory proteins in cells undergo folding in the endoplasmic reticulum with the introduction of disulfide bonds and acquire the correct three-dimensional structure. Disulfide bonds are especially important for protein folding. It has been thought that formation of protein disulfide bonds in eukaryotes is mainly carried out by an enzyme called protein disulfide isomerase. Proteins, bearing the C-terminus of amino acids sequences with His-Asp-Glu-Leu (HDEL) sequence in yeast, in the endoplasmic reticulum (ER), which is a eukaryotic cellular organelle involved in protein synthesis, processing, and transport, have been considered to recycle between ER and Golgi apparatus. The proposal for this recycling model derives from the study of an HDEL-tagged fusion protein. Here, the localization and oligosaccharide modification of protein disulfide isomerase were investigated in yeast, and showed the first direct evidence that this intrinsic ER protein transports from ER to Golgi. Results suggest that this native protein is also accessible to post-ER enzymes, and yet accumulates in the ER.

\section{INTRODUCTION}

A commonly used microorganism in biotechnology is Escherichia coli. This versatility is because of its fully sequenced genomic gene. Prokaryote is an easy-to-culture for expressing recombinant genes. However, in prokaryote cells, post-translational modification of proteins is significantly different compared to eukaryotes, or missing. Attempts to express human genes in E. coli often result in the absence of 
biologically active proteins or precipitation as inclusion bodies in cells $[1,2]$. Originally in eukaryotes, newly synthesized polypeptide should be folded in the endoplasmic reticulum to form the unique conformation, but Escherichia coli does not have such a mechanism.

Protein folding is resulted mainly due to the oxidation of thiol groups (-SH) of cysteine residues to form (-S-S-). Correct disulfide bonds are essential for the tertiary and subsequent quaternary structures of proteins and for the biological activity of mature proteins [3]. A large number of cysteine residues increase the probability of forming an incorrect disulfide bond. Improving misfold of protein has been a long-standing challenge in the field of biotechnology. In general, organisms have enzymes that catalyze refolding of misfolded disulfide bonds and repair correctly. Protein disulfide isomerase (PDI) is known as a representative of refolding enzyme, which is present in the endoplasmic reticulum (ER) [4].

In the yeast Saccharomyces cerevisiae, the carboxyterminal sequence (HDEL) has been considered to function as an ER retention signal. This signal does not prevent proteins in the ER to export from it, but allows their retrieval from later compartments of secretory pathway. Pelham et al. have demonstrated this recycling model by the finding that proteins with an ER retention signal can undergo carbohydrate modifications that occur only in early Golgi compartments [5]. They also showed in genetic studies in yeast the existence of the receptor for recycling of ER proteins as the product of the ERD2 gene [6]. However, the evidence for this model derives from experiments that showed an artificial prepro $\alpha$-factor fusion protein, tagged at the carboxyl terminus with the HDEL sequence, accumulates intracellularly as a precursor containing both ER- and Golgi-specific oligosaccharide modifications in yeast Saccharomyces cerevisiae.

In previous experiments, an ER protein PDI have purified from $S$. cerevisiae and determined its sequence of gene. Previous results revealed that this enzyme is an $\mathrm{N}$-glycosylated glycoprotein containing about 5 core oligosaccharides $[7,8]$. Taking advantage of this property, it was examined whether yeast PDI was modified with Golgi-specific glycosylation.

\section{MATERIALS AND METHODS}

\subsection{Yeast Cells and Culture Condition}

TM5 (MATa pho3 pho5 trp1 leu2 ura3 his3) cells were selected as Yeast Saccharomyces cerevisiae. To be expressed a large amount of PDI, TM5 was harboring multicopy plasmid Yep13 containing the PDI1 gene. The yeast cells were grown at $24^{\circ} \mathrm{C}$ for $18 \mathrm{~h}$ and harvested. For radioisotope labelling cells in Yeast, Saccharomyces cerevisiae X2180-1A (MAT a, gal 2, cup 1) strain and temperature sensitive mutant HMSF176 (MAT $\alpha$, sec 18-1) strain were used.

\subsection{Fractionation of Yeast Cell Extracts}

To investigate the intracellular location of the PDI in yeast, yeast cell extracts were fractionated in sucrose density gradient as described by Ruohola et al. [9]

Yeast cells $\left(100 \mathrm{OD}_{600}\right.$ units) were then resuspended in $1 \mathrm{~mL}$ of the spheroplast medium (1.4 M sorbitol, $50 \mathrm{mM}$ potassium phosphate, $56 \mathrm{mM} \beta$-mercaptoethanol, $\mathrm{pH} 7.5)$ containing zymolyase $(1 \mathrm{mg} / \mathrm{mL})$ and converted to spheroplasts for $1 \mathrm{~h}$ at $38^{\circ} \mathrm{C}$. After centrifuging these sedimented spheroplast mixtures in sorbitol cushion (1.7 M sorbitol, $20 \mathrm{mM}$ sodium phosphate, $\mathrm{pH}$ 7.5), purified spheroplasts were resuspended in $4 \mathrm{~mL}$ of the lysis buffer (0.3 M mannitol, $10 \mathrm{mM}$ Mops, $\mathrm{pH}$ 7.0) containing $N, N$-diphenyl-p-phenylene diamine $(0.1 \mathrm{mg} / \mathrm{mL})$ and aprotinin $(100 \mathrm{U} / \mathrm{mL})$. The homogenization was also performed according to $\mathrm{Ru}-$ ohola et al. [9], and finally, $3 \mathrm{~mL}$ of homogenate in $60 \%(\mathrm{~W} / \mathrm{W})$ sucrose was obtained. Two milliliter of homogenate was placed at the bottom of an ultracentrifuge tube and overlaid with the following sucrose solutions: $1 \mathrm{~mL}$ of $55 \%$ sucrose, $1.5 \mathrm{~mL}$ each of $50 \%, 45 \%, 40 \%$ and $35 \%$ sucrose and $2 \mathrm{~mL}$ of $30 \%$ sucrose. The gradient was centrifuged at $4^{\circ} \mathrm{C}$ for $12 \mathrm{~h}$ at $170,000 \times g$ and fractionated in microtubes. A total of 23 factions, each about $500 \mu \mathrm{L}$, were collected in microtubes using a gradient tube fractionator, and then, the density of sucrose in each fraction was determined by refract meter. 


\subsection{Determining of Distribution of Yeast Organelle by Assaying Marker Enzymes}

As marker enzymes of the distribution, NADPH-cytochrome c reductase, Kex2 and $\alpha$-mannosidase were used. Their assays were directly performed as described [10-12], the PDI assay was performed as described by Mizunaga et al. [7] after buffer of each fraction was replaced to $50 \mathrm{mM}$ sodium phosphate buffer ( $\mathrm{pH}$ 7.5) containing $50 \mathrm{mM}$ EDTA.

\subsection{Immunoprecipitation of Radioisotope Labelled Yeast Cell Extracts}

Saccharomyces cerevisiae X2180-1A (MAT a, gal 2, cup 1) strain and temperature sensitive mutant HMSF176 (MAT $\alpha$, sec 18-1) strain [13] grown at $24^{\circ} \mathrm{C}$ were labeled with ${ }^{35} \mathrm{~S}$ (Trans ${ }^{35} \mathrm{~S}$-label Metabolic Labeling Reagent, ICN) for $30 \mathrm{~min}$ at $24^{\circ} \mathrm{C}$ or $37^{\circ} \mathrm{C}$ and collected as described in reference [5]. After washing once with $10 \mathrm{mM}$ sodium azide, radiolabeled cells were resuspended at $100 \mathrm{OD}_{600} \mathrm{units} / \mathrm{mL}$ in 50 $\mathrm{mM}$ Tris- $\mathrm{HCl}$ buffer (pH7.5) containing 1\% SDS and $1 \mathrm{mM}$ phenylmethylsulfonylfluoride and homogenized as described in reference [7]. Cell extracts were boiled for $5 \mathrm{~min}$, and debris were removed by centrifugation for $5 \mathrm{~min}$ at $6000 \times \mathrm{g}$. Two hundred microliter of respective supernatants were diluted with 800 $\mu \mathrm{L}$ of ice cold 1.25\% TritonX-100 in $60 \mathrm{mM}$ Tris- $\mathrm{HCl}$ buffer (containing $190 \mathrm{mM} \mathrm{NaCl}$ and $6 \mathrm{mM}$ EDTA, $\mathrm{pH7.4)}$ and immunoprecipitated for $12 \mathrm{~h}$ at $4^{\circ} \mathrm{C}$ by addition of $10 \mu \mathrm{L}$ of anti-PDI antibody [7] followed by addition of $50 \mu \mathrm{L}$ of $20 \%$ protein A-Sepharose suspension. Samples were rotated at room temperature for 2 h.

Immnunoprecipitates were washed twice with $1 \mathrm{~mL}$ RIPA buffer $(0.5 \mathrm{M} \mathrm{NaCl} ; 50 \mathrm{mM}$ Tris- $\mathrm{HCl}$ [pH7.4]; 0.5\% NP-40; 0.5\% deoxycholate; $0.1 \%$ SDS), followed by two washes with PBS. At this stage, each sample was either divided for SDS-PAGE or for reimmunoprecipitation against anti- $\alpha-1,6$ mannose antibody. For SDS-PAGE, samples were then resuspended in SDS sample buffer, boiled for 5 min and analyzed by SDS-PAGE. For the second immnunoprecipitation, anti-PDI antibody reactive proteins were eluted from the resin by adding $50 \mu \mathrm{L}$ of $1 \%$ SDS in $50 \mathrm{mM}$ Tris- $\mathrm{HCl}(\mathrm{pH} 7.4)$ and boiled for $5 \mathrm{~min}$. Eluted proteins were reprecipitated with the appropriate anti- $\alpha-1,6$ mannose antibody and then also analyzed by SDS-PAGE as described above. The electrophoresed gel was treated with Amplify, dried and exposed to an $\mathrm{X}$-ray film.

\section{RESULTS AND DISCUSSION}

\subsection{Yeast PDI Was Localized in ER}

The result was shown in Figure 1. Activities of PDI and NADPH-cytochrome c reductase, known as an ER marker enzyme, co-migrated. Kex2, known as a Golgi marker enzyme, is eluted in the 5 - 6 fractions before the PDI's peak fraction. $\alpha$-Mannosidase, as a vacuole marker enzyme, is clearly separated from the activities of NADPH-cytochrome $c$ reductase and PDI.

\subsection{Evidence That Yeast PDI in ER Was Also Transported to the Golgi Apparatus}

It has been also demonstrated that addition of $\alpha-1,6$ linked mannose residues occurs especially in yeast early Golgi apparatus, like that of mammalian cells [13]. Anti- $\alpha-1,6$ mannose antibody was used to determine whether yeast PDI obtains this Golgi-specific glycosylation and attempted to demonstrate recycling of PDI from the Golgi to the ER.

As shown in Figure 2, PDI extracted from X2180-1A cells radiolabeled at either $24^{\circ} \mathrm{C}$ or $37^{\circ} \mathrm{C}$ (lane 1 and 2) had acquired the $\alpha-1,6$ mannose addition, as evidenced by the precipitation of $\alpha-1,6$ mannose-containing material with anti- $\alpha-1,6$ mannose antibody (lane 8 and 9 ).

Similarly, PDI extracted from secl8 mutant cells labeled at the permissive temperature $\left(24^{\circ} \mathrm{C}\right)$ (lane 3 ) also had acquired the $\alpha-1,6$ mannose addition (lane 6). On the other hand, when sec18 cells were radiolabeled at the nonpermissive temperature $\left(37^{\circ} \mathrm{C}\right.$ ) (lane 4), PDI extracted from them showed no reactivity with anti- $\alpha-1,6$ mannose antibody (lane 7 ). At the nonpermissive temperature, all vesicular traffic is 


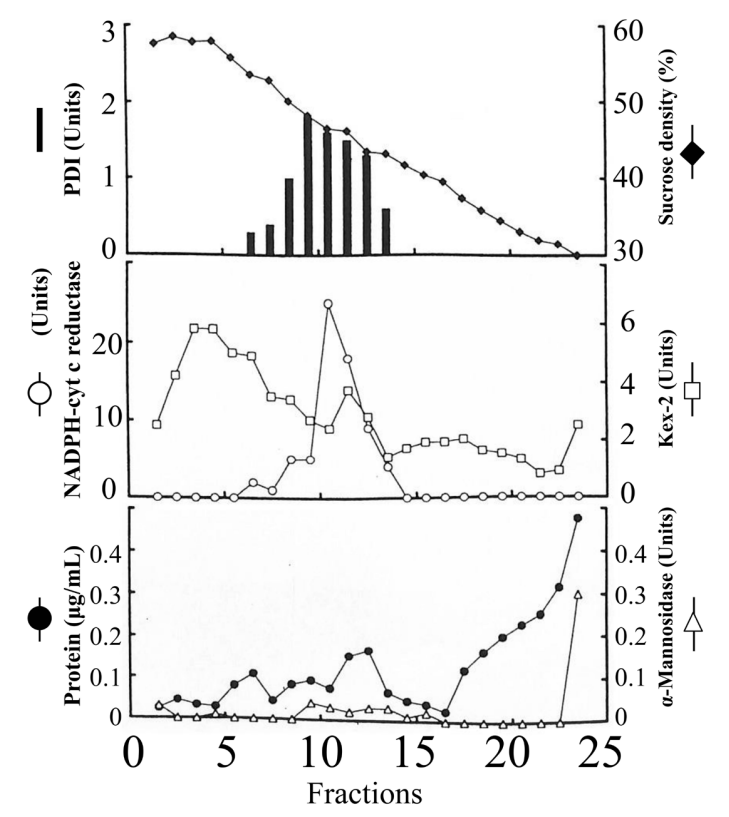

Figure 1. PDI co-migrates with NADPH-cytochrome c reductase activity. Cells of $S$. cerevisiae TM5, harboring multicopy plasmid Yep13 containing the PDI1 gene, were fractionated, and activities of marker enzymes and PDI were determined as described in text.

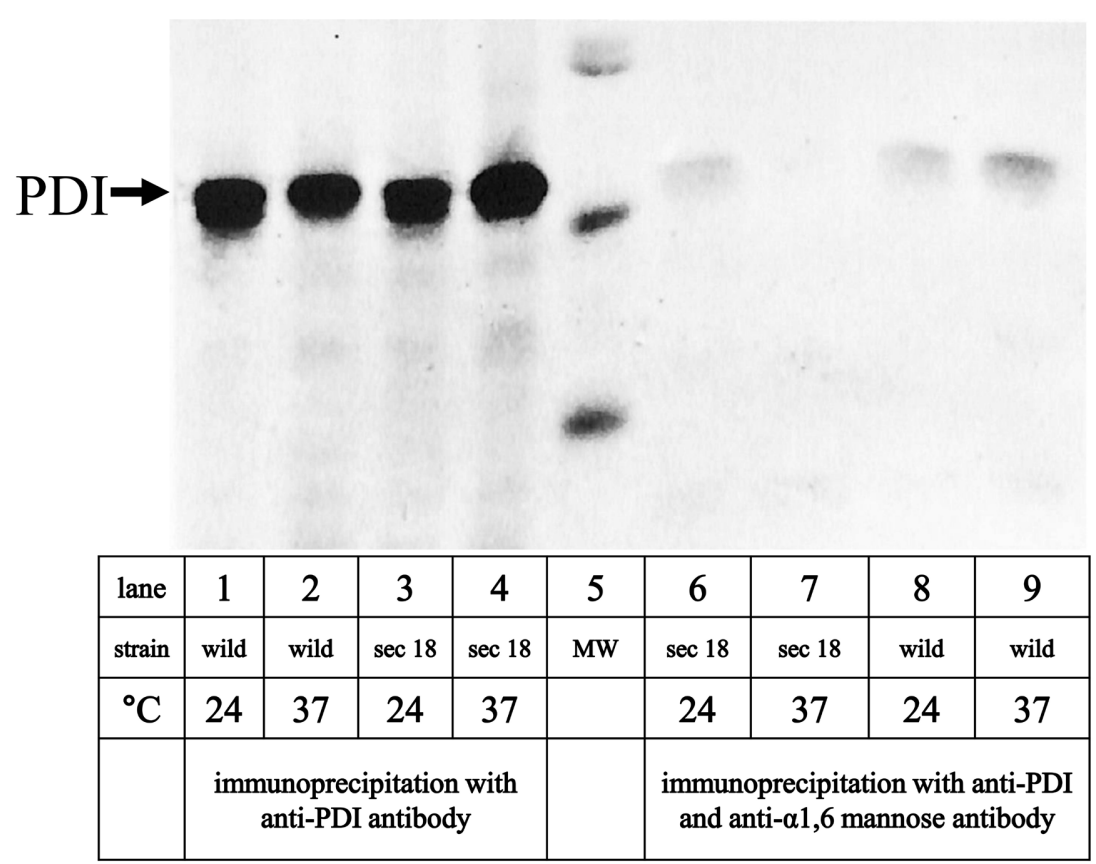

Figure 2. PDI receives $\alpha-1,6$ linked mannose additions in vivo. Wild-type (X2180-1A) and sec18 (HMSF176) cells were labeled for 30 min either at the permissive $\left(24^{\circ} \mathrm{C}\right)$ or nonpermissive temperature $\left(37^{\circ} \mathrm{C}\right)$. Equal aliquots of cell lysates were immunoprecipitated with either anti-PDI antibody or anti-PDI antibody followed by a second precipitation with anti- $\alpha$-1,6 mannose antibody. Immunoprecipitates were analyzed by electrophoresis on SDS-PAGE followed by autoradiography. The molecular weight standards (MW) were phosphorylase b $(97,000)$, bovine serum albumin $(68,000)$, and ovalbumin $(43,000)$. 
blocked in sec18 mutant, and newly synthesized proteins cannot leave the ER $[14,15]$. These results suggested that the luminal ER protein, PDI, had reached the early Golgi compartment and received $\alpha-1,6$ mannose addition.

\section{CONCLUSION}

It was demonstrated here that the luminal ER protein, PDI, is also accessible to Golgi-specific modifying enzymes, and yet accumulates in the ER. The results in this research study proposed the first direct evidence using a native protein in yeast that a luminal ER protein, PDI, transports from the ER to the Golgi compartment, and strongly supported the recycling model of the luminal ER protein that Pelham H.R. et al. have proposed. The evidence that PDI wasn't seen in the Golgi fraction in Figure 1 gives a view that PDI, once goes to early Golgi compartment, quickly returns to ER, so, the bulk of PDI resides in the ER. Clarifying intracellular localization of PDI, which catalyzes repairing of incomplete protein conformations, leads to promoting increased efficiency in industrial application of biomaterials, such as artificial antibodies, by performing correct folding on nascent proteins while maintaining bioscientific activity. Further research is necessary to prove the phenomenon that yeast PDI, that is once transported from the ER to the Golgi, returns from the Golgi to the ER.

\section{ACKNOWLEDGEMENTS}

This work was supported by JSPS KAKENHI (Grant Numbers 16K11635 and 21K10030). The authors thank Dr. A. Nakano at Tokyo University for providing $\alpha$-1,6 mannose antibodies. The authors would like to thank Dr. H. Tachikawa and other members, Tokyo Univ. for their support in these experiments. The authors would like to thank Dr. X D. Gao, Tokyo Univ., for his assistance with the English language of this manuscript. This paper would be sent in memory of Prof. Yoshiharu Maruyama.

\section{CONFLICTS OF INTEREST}

The authors declare no conflicts of interest regarding the publication of this paper.

\section{REFERENCES}

1. Kane, J.F. and Hartley, D.L. (1988) Formation of Recombinant Protein Inclusion Bodies in Escherichia coli. Trends in Biotechnology, 6, 95-101. https://doi.org/10.1016/0167-7799(88)90065-0

2. Hwang, P.M., Pan, J.S. and Sykes, B.D. (2014) Targeted Expression, Purification, and Cleavage of Fusion Proteins from Inclusion Bodies in Escherichia coli. FEBS Letters, 588, 247-252. https://doi.org/10.1016/j.febslet.2013.09.028

3. Banach, M., Kalinowska, B., Konieczny, L. and Roterman, I. (2016) Role of Disulfide Bonds in Stabilizing the Conformation of Selected Enzymes-An Approach Based on Divergence Entropy Applied to the Structure of Hydrophobic Core in Proteins. Entropy, 18, 67. https://doi.org/10.3390/e18030067

4. Wilkinson, B. and Gilbert, H.F. (2004) Protein Disulfide Isomerase. Biochimica et Biophysica Acta-Proteins and Proteomics, 1699, 35-44. https://doi.org/10.1016/S1570-9639(04)00063-9

5. Dean, N. and Pelham, H.R. (1990) Recycling of Proteins from the Golgi Compartment to the ER in Yeast. Journal of Cell Biology, 111, 369-377. https://doi.org/10.1083/jcb.111.2.369

6. Semenza, J.C., Hardwick, K.G., Dean, N. and Pelham, H.R. (1990) ERD2, a Yeast Gene Required for the Receptor-Mediated Retrieval of Luminal ER Proteins from the Secretory Pathway. Cell, 61, 1349-1357. https://doi.org/10.1016/0092-8674(90)90698-E

7. Mizunaga, T., Katakura, Y., Miura, T. and Maruyama, Y. (1990) Purification and Characterization of Yeast Protein Disulfide Isomerase. The Journal of Biochemistry, 108, 846-851.

https://doi.org/10.1093/oxfordjournals.jbchem.a123291 
8. Tachikawa, H., Miura, T., Katakura, Y. and Mizunaga, T. (1991) Molecular Structure of a Yeast Gene, PDI1, Encoding Protein Disulfide Isomerase That Is Essential for Cell Growth. The Journal of Biochemistry, 110, 306-313. https://doi.org/10.1093/oxfordjournals.jbchem.a123576

9. Ruohola, H. and Ferro-Novick, S. (1987) Sec53, a Protein Required for an Early Step in Secretory Protein Processing and Transport in Yeast, Interacts with the Cytoplasmic Surface of the Endoplasmic Reticulum. Proceedings of the National Academy of Sciences of the United States of America, 84, 8468-8472.

https://doi.org/10.1073/pnas.84.23.8468

10. Kreibich, G., Urich, B.L. and Sobatini, D.D. (1978) Proteins of Rough Microsomal Membranes Related to Ribosome Binding. I. Identification of Ribophorins I and II, Membrane Proteins Characteristics of Rough Microsomes. Journal of Cell Biology, 77, 464-487. https://doi.org/10.1083/jcb.77.2.464

11. Chan, R.K., Melnick, L., Blair, L.C. and Thorner, J. (1983) Extracellular Suppression Allows Mating by Pheromone-Deficient Sterile Mutants of Saccharomyces cerevisiae. Journal of Bacteriology, 155, 903-906. https://doi.org/10.1128/jb.155.2.903-906.1983

12. Opheim, D.J. (1978) $\alpha$-D-mannosidase of Saccharomyces cerevisiae Characterization and Modulation of Activity. Biochimica et Biophysica Acta, 524, 121-130. https://doi.org/10.1016/0005-2744(78)90110-9

13. Dulary, E., Yu, S.Y., Houdou, M., de Bettignies, G., Decool, V., Potelle, S., Duvet, S., Krzewinski-Recchi, M.A., Garat, A., Matthijs, G., Guerardel, Y. and Foulquier, F. (2018) Investigating the Function of Gdt1p in Yeast Golgi Glycosylation. Biochimica et Biophysica Acta-General Subjects, 1862, 394-402. https://doi.org/10.1016/j.bbagen.2017.11.006

14. Novick, P., Ferro, S. and Schekman, R. (1981) Order of Events in the Yeast Secretory Pathway. Cell, 25, 461-469. https://doi.org/10.1016/0092-8674(81)90064-7

15. Schuldiner, M., Collins, S.R., Thompson, N.J., Denic, V., Bhamidipati, A., Punna, T., Ihmels, J., Andrews, B., Boone, C., Greenblatt, J.F., Weissman, J.S. and Krogan, N.J. (2005) Exploration of the Function and Organization of the Yeast Early Secretory Pathway through an Epistatic Miniarray Profile. Cell, 123, 507-519. https://doi.org/10.1016/j.cell.2005.08.031 